Systems Practice, Vol. 9, No. 4, 1996

\title{
A Typology of Power Supporting Intervention
}

\author{
Robert L. Flood ${ }^{1}$ and Norma R. A. Romm ${ }^{1}$
}

Received July 1, 1995

A typology of power is presented. The typology guides researchers/practitioners to the main concerns currently debated about power and its abuses. Possible ways of managing organisational issues explicitly dealing with power and abuses are explored. The typology forms three arenas of discourse to make this possible: structuralism, intersubjective decision making, and might-right management. Structuralism deals with issues surrounding organisational design and process design. Intersubjective decision making deals with issues surrounding processes of debate. Might-right management deals with issues surrounding disempowering social practices that impact on designing and debating. The arenas of discourse suggest ways, that differ, of understanding and managing a range of issues related to the operation of power. This is part of a wider project called Diversity Management, which in turn is part of Critical Systems Thinking.

KEY WORDS: typology of power; managing power; Diversity Management; Critical Systems Thinking.

\section{INTRODUCTION}

Approaches to intervention have matured considerably in recent years. A persistent and, in our view, fair criticism, however, is that these approaches have not dealt adequately with power and its abuses. As part of our counter-measure, we establish in this paper a platform for discussion on this topic. We form a typology of power that reflects different possibilities for intervention practices towards improved management of power.

The typology organises three arenas of discourse around three issue areas: structuralism, intersubjective decision making, and might-right management. Structuralism deals with power issues encircling organisational design and process design when inefficiency or ineffectiveness in design are thought to prevail. Intersubjective decision making deals with power issues encircling processes of debate, relevant insofar as there is no clear-cut view on strategies to pursue or other ways forward such as choice of design. Might-right management deals with disempowering social practices that can lead to a lack of relevance of

\footnotetext{
${ }^{1}$ Centre for Systems Studies, School of Management, University of Hull, Hull HU6 7TQ, UK.
} 
designs to (many of or some of) those who have to live with experienced consequences of them or a lack of influence in debating processes leaving decisions ill-considered for (many of or some of) those who have to live with experienced consequences of them. The arenas of discourse isolated by the typology not only provide different conceptions of power, but also suggest possible practical responses to abuses of power. ${ }^{2}$

We begin by positioning our typology of power in the literature of such typologies. This brings our work into focus. Then each of the three arenas of discourse reflecting types of intervention is explored. The order of presentation is structuralism, intersubjective decision making, and might-right management. We then conclude.

\section{TYPOLOGIES OF POWER}

To surface and bring into focus our typology of power we first explore the literature of such typologies. Two typologies were found particularly useful and so shape the text, whilst some other important work in this area is dealt with briefly in footnotes. The two main typlogies we draw upon are summarised from original accounts of their artisans, Oliga (1996) and Clegg (1989).

Oliga suggests a division between what he calls "objectivist," "subjectivist," and "relational" perspectives. With objectivism he refers to theories that focus on power as capacities located in social structures. These tend to be either synergistic (e.g., Parsonian collective-see Section 3.2) or conflictual (e.g., Marxian conflictual-see Section 3.3) theoretical orientations. With subjectivism he discusses theories that focus on power possessed by agents. With relational approaches he places theories that conceive power as a property of interaction among social forces. ${ }^{3}$

\footnotetext{
${ }^{2}$ The suggestion here to concentrate on separate arenas of discourse that involve different visions of the world draws on Kuhn's (1970) conception of paradigms. However, Flood and Romm (1996) suggest that the location of discourses needs to be tied to a conception of responsible choice making in the face of diversity - in this case, the diversity of ways of seeing power.

${ }^{3}$ Comparable categorisations have also been recognised by other commentators. See, for example, Knights and Vurdubakis's (1994: 170) reference to functionalist (including Marxist-oriented functionalism), voluntarist, and relational approaches. Consider, too, how Morgan's (1980, p. 608) four paradigms can translate into a threefold categorisation, because he sees functionalist and radical structuralist approaches as being objectively oriented. These orientations are distinguished from interpretive ones focusing on agents' meaning-making, and from "radical humanist" agendas which concentrate on readdressing human relationships. Morgan (1980, p. 612) believes that these categorisations may be relevant to encourage what he calls a spirit of critical inquiry which cautions against excessive commitment to any particular point of view. This tallies to a large extent with the proposals of Gouidner (1973, pp. 489-495), who in locating functionalist, interpretive, and critical theoretical types of argumentation, calls for a (self)-reflexive relationship to all of them. Clegg's $(1989$, p. 37) discussion of circuits of power, discussed below, represents an attempt to relate alternative theoretical orientations to a framework which may allow us to avoid using any one conception of power.
} 
Oliga recognises that his typology bears some likeness to Clegg's (1989) trifold "circuits of power." These circuits, as Clegg defines them, refer to distinct conduits through which power may pass in society. Clegg relates these passageways to theoretical arguments in the literature on power. He sees his "circuits of power" as grounded in "the grammar of power as a concept" (Clegg, 1989, p. 239). Clegg's first circuit, the "dispositional" circuit, focuses on the structure of social rules and the way they incorporate the capacity to mobilise bias. ${ }^{4}$ It draws on structuralist argumentation, seeing power rooted in objective capacity (Clegg, 1989, pp. 209-210) and resembles Oliga's objectivism. Clegg's (1989, p. 214) next circuit, the "episodic" circuit, views agency(ies) as paramount. It matches Oliga's subjectivism. This includes pluralist conceptions of episodic power and may allow for the exploration of pluralist or elitist power exercised in specific contexts. ${ }^{5}$ The third circuit, the "facilitative" circuit, identifies possibilities for transformative action through empowerment (Clegg, 1989, p. 227). The facilitative category is presented as a broad category for collecting all references to productive power ${ }^{6}$-although Clegg $(1989$, p. 236) concentrates here on the facilitative possibility of resisting relationships of domination by generating alternative modes of relationship. With this focus the facilitative category can be seen to match up with Oliga's relational approach.

We suggest that it is possible to spread the notion of facilitative power across the three arenas of discourse, drawing out different facilitative possibilities as they arise in these arenas. We present our rationale for this in Sections 3,4 , and 5. The kinds of facilitation offered in our two other arenas of discourse (which correspond more or less with Clegg's dispositional and episodic circuits) are differentiated by their focus: structuralism offers a (facilitative) notion of power to coordinate by design, and intersubjective decision making highlights the (facilitative) power of the intersubjective process to aid decision making. In effect we have translated Clegg's circuits into arenas of discourse that all allow for intervention toward improved use of power so as to minimise its abuses.

We have a practical interest in intervention as well as an interest in theoretical reasoning. In the structuralist arena the practical question becomes, How can design aspire to optimum relevance in the minds of those who have to live with the consequences of design? In the intersubjective decision-making arena the practical question becomes, What do decision making processes involve that may influence how well-considered decisions turn out to be in the minds of

\footnotetext{
${ }^{4}$ Here Clegg (1989, p. 76) refers to the celebrated work of Bachrach and Baratz (e.g., 1962, p. 95) to point to the way in which the "rules of the game" may allow for non-decision making to take place so that items which may be relevant to the concerns of some classes in society are left off the agenda of social discussion.

sSee also Lukes (1974, p. 11) on the notion of "pluralism" as being sufficiently open to incorporate elements of "nonplurality." Dahl's (1961) argument is cited as such a position.

${ }^{6}$ This allows Clegg $(1989$, p. 15$)$ to place Parsons in this category too.
} 
those who will live with the consequences of them? In the might-right management arena the practical question becomes, Why should we believe and trust that power relations can shift to aspire to new forms of social relationship. ${ }^{7,8}$

Each of the three arenas of discourse are now explored. The order of presentation is structuralism, intersubjective decision making, and might-right management. ${ }^{9}$

\section{STRUCTURALISM}

\subsection{Opening Remark}

We have chosen to introduce our thoughts on structuralism through two lines of discourse, Parsonian and Marxian, in that order.

\subsection{Parsonian Discourse}

Parsons' structural-functional position is premised on the idea that power is primarily a collective resource. It promotes a synergistic view of power as a collective property of "the system." We referred to this when introducing Oliga's classification in Section 2. Power to attain goals is seen as a normal part of the functioning of all systems-including social ones. This analysis applies at the level of society as a social system as well as all other "systems" in society. So, for social systems to be stable, they need a stable base of (legitimate) power, vested in part of "the system" geared toward attaining collective goals. A goal attainment subsystem is institutionalised to serve the collective. Parsons (1973, p. 271) admits, however, that "the whole problem of the institutionalisation of authority so as to insure adequate acceptance where necessary and

\footnotetext{
${ }^{7}$ This may also involve assessing why entrenched modes of relations become sustained. It is not to be confused, however, with Bhaskar's (1993, p. 392, 1994, p. 218) type of questioning, which invokes the display of structural absences in the system which are to be remedied. The analytic focus in Bhaskar's (1994, p. 221) conception of "transformative capacity" is a route to real relations that require transformation. This fits uneasily with the "medley" of philosophers to whom he refers (Bhaskar, 1994, p. 215), including Derrida, Habermas, and Foucault, all nonrealists who are wary of making realist-oriented distinctions between "truth" and "illusion," for they believe that this in itself may threaten the creation of new forms of social relationship.

${ }^{8}$ Flood's (1993b) conception of freedoms made possible through design, debate and disemprisonment and his conception of alternative priorities written into How? What? and Why? questions (Flood, 1995) link up with the argument here.

${ }^{9}$ Our argument concentrates on emancipatory possibilities in society. However, it should be noted that these possibilities also imply new ways of addressing eco-friendly relationships with nature, through, for example, developing designs geared to respect nature, establishing alternative decisionmaking priorities, and redefining our being through our involvement with nature
} 
protect against its abuses is difficult." ${ }^{, 10} \mathrm{He}$ admits that there may be a tendency for those strategically placed to exploit the weaker (Parsons, 1973, p. 371). Despite this, Parsons argues that measures can be taken to control and counteract such tendencies. Parsons $(1957,1963)$ thus concentrates on power as "power to" serve collective goals.

\subsection{Marxist-Oriented Discourse}

The view of power sometimes called the Marxist conflict view ${ }^{11}$ concentrates on identifying instances of "power over" (rather than "power to"). It converges debate on the way in which vested interests may be served by systematic entrenchment of dependencies in class systems. It is suggested that the mechanisms of the capitalist system, in particular, are geared to meeting the needs of some people at the expense of others (see, e.g., Bachrach and Baratz, 1962; Ojo, 1983; Bhaskar, 1994). The "power over' argument has been extended to deal with many structures and their biases other than class structure. For such theorists, it is important to generate alternative structures that will be more conducive to serving collective goals/interests. Within Marxist argument, discussion of possibilities for coordination at both societal and smaller scale organisational level is still going on (see, e.g., Sayer and Walker, 1992).

\subsection{Implications for Practice}

Intervention suggested by structuralist discourse is about setting up designs that facilitate the way in which collective goals can be served. In essence, structuralism proposes design solutions to potential or actual bases of power. Structure can be designed sensitively to allow for coordination of efforts to aspire to collective goals irrespective of the scale of operation. Structuralist discourse sensitises us to abuses that can occur when design issues are not delicately addressed and managed. The graph in Fig. 1 depicts intervention possibilities and provides a stimulant to a practically oriented discourse about design.

Figure 1 abets debate about better designs, i.e., design relevant to coordination of efforts. On the graph, better design is represented by movement from the point of "structure" on the $X$ axis, upwards towards "most relevance" on the $Y$ axis, so as to maximise "a." The point marked " $\mathrm{A}$ " is a point which

\footnotetext{
${ }^{10}$ Parsons argues that power, as he defines it, cannot be abused because by definition it is the capacity to serve collective goals. This does not mean, however, that abuses of authority are hereby excluded from his view. What it means is that he defines them under a different label. Nevertheless, the complaint of authors such as Gouldner (1973), Giddens (1977), and Wrong (1995), is that Parsonians may be overoptimistic about the propensity for collective goal attainment via the capacity of power.

"So named by, for example, Oliga (1996), Wrong (1995), and Zhichang (1995).
} 


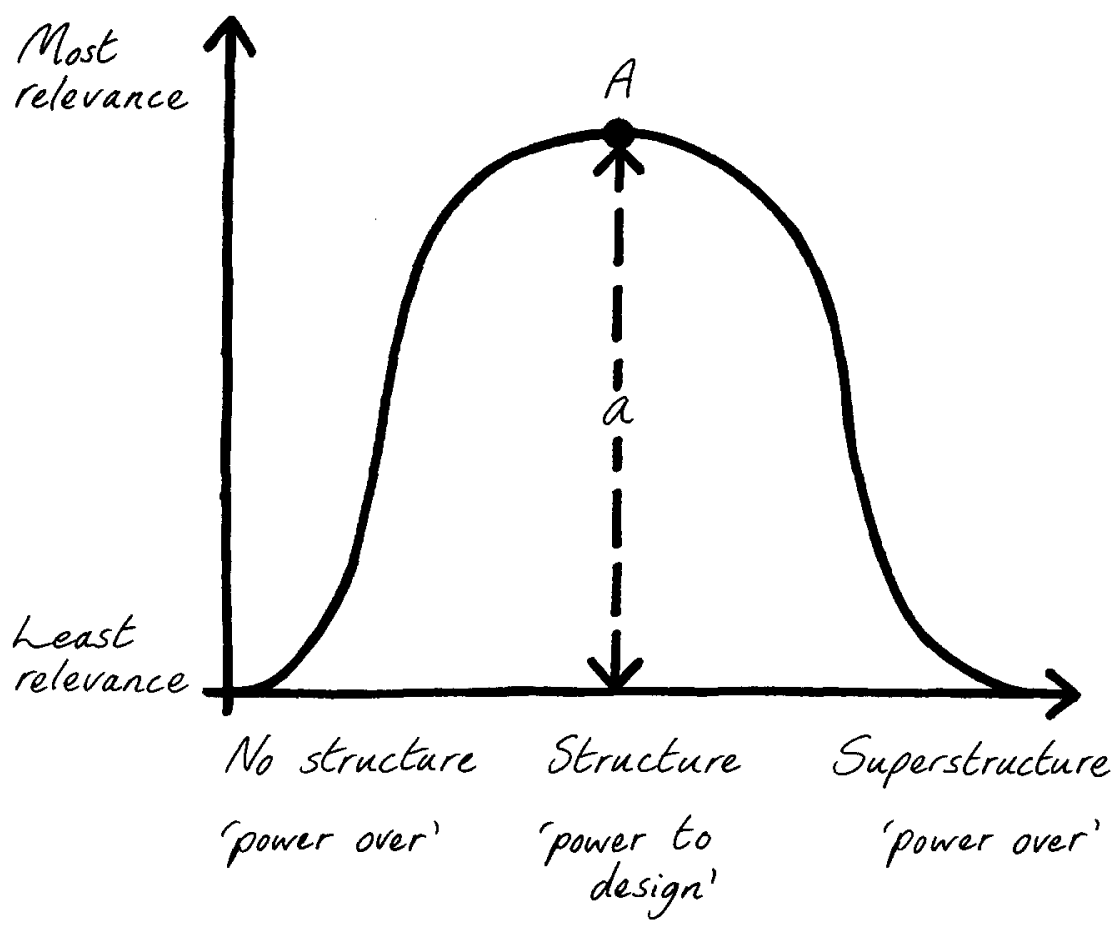

Fig. 1. The structural arena of discourse: design management. The word "superstructure" is not being used in the Marxist sense of the term-where "superstructure" implies features of existence such as the polity, legal institutions, family relationships, belief systems, etc. It is being used here as the opposite of "no structure."

marks an ideal. Our suggestion is to study optional designs with the aim of pushing " $a$ " upwards, toward realising the ideal of a most relevant design for the circumstances. ${ }^{12}$ Failing this, "no structure" and "superstructure" begin to stifle choice making of participants and hence reduce freedom. In no structure, there is control by inefficiency and its demands (Beer, 1973; Flood, 1993b, pp. 9-10). In superstructure, rules and procedures of the system become the controlling force (Beer, 1973; Hofstede, 1994, p. 135).

No structure and superstructure are shown on the $X$ axis as abuses of power (here labelled "power over"). The further left we move on the graph, the less relevant are designs because of lack of structure, as indicated by the graph itself which falls away from the ideal. The left extreme on the $X$ axis resonates with situations where people have to cope with consequences of insufficient structural

${ }^{12}$ Circumstances means the situation as seen in terms of a chosen focus of attention. This allows people to get involved in defining the issues. Suitability of design therefore is subject to circumstances. There is no right design independent of interventionists. If circumstances change such that there is a different mix of people, the discussion on suitability of design may change too. 
arrangements (that is, of rules coordinating the pattern of conduct). People become frustrated by ad hoc rulings that are created to deal with issues on contingent bases as a matter of course. In management speak this is a form of crisis management, one where concerned participants find the lack of reliability frustrating or even threatening. At the right extreme, by contrast, there is an excessive focus on rules, to the extent that organisational activities become regimented responses to rule following. The further right we move on the graph, the less relevant are designs because of too much structure, as indicated by the graph itself, which again falls away from the ideal. Here, power capacities invested in "the rules," or the appeal to so-called rightness of a style of coordination, become (ab)used to define organisational responses that are expected (of others).

Neither of these extremes, however, has absolute meaning independent of the context of their use. That is why we keep making reference to "circumstances." So, for example, what some people experience as a frustrating lack of rules, others may find refreshing. Similarly, what some may regard as a suitably pitched design for organisational coordination, others may encounter as superstructure. This points to the significance of the experience of structure and, in this sense, transcends structuralist positions as expounded by some structuralist authors mentioned above (including authors stressing the importance of more adhocratic or informal designs). This is because the focus of many structuralist arguments is largely "getting the structure right." This can result in a structuralist mentality on the part of professional theorists as well as lay theorists. A structuralist mentality can exclude ways of addressing the design issue, for example, through debate about the experience of structure. To concentrate on experience of structure may indeed require a shift in perspective. Our argument encourages theoreticians and interventionists to be sufficiently open to acknowledge this. [See Flood and Romm (1996), for an elaboration of this argument.] The discussion in Section 4 on intersubjective decision making carries this point forward.

\section{INTERSUBJECTIVE DECISION MAKING}

\subsection{Discourse}

The intersubjective decision-making arena of discourse concentrates on ways that people make decisions in conjunction with other people (or agents). ${ }^{13}$ Theorists of this persuasion do not believe that the way events work out in everyday life is due to capacities written into social nules, or resource distribution, or official definitions of authority, or any other feature of design. They

\footnotetext{
${ }^{13}$ This dynamic is difficult at times to disentangle from might-right dynamics. This becomes especially apparent when actually attempting to disentangle practical cases.
} 
prefer to highlight the central role of agency in both defining and using rules and resources and authority (including the way in which other agents respond to such use).

The intersubjective view provides an alternative to structuralist discourse. Many critics of the intersubjective view complain that it cannot address the issue of how and why power is exercised because it concentrates too much on episodes of interaction (issues picked up in the next section). The counter-contention is that it can address the problematics of power, however, it does so in different terms.

Power is seen as something to be used in the course of interaction, but its exercise is conditional on the way that the user and others involved in the interaction define events. Theorists argue that this theoretical conception resonates well with people's experience of power in everyday life. The opportunity for people to influence decision making occurs in the process of interaction. Here, meanings are exchanged and perceptions defined and redefined (Czarniawska-Joerges, 1993, p. 56). Power to influence depends on other agents' responses. However, neither observers nor agents know in advance how much power others possess (Dandridge, 1985, pp. 145-146; Knorr-Cetina, 1988, pp. 46-47; Romm, 1994a, pp. 333-334).

The amount of power possessed can never be defined outside the way things are worked out in the process of interaction. People may, for instance, decide to draw (predictably or unpredictably) on third parties as means of influencing decisions. They may struggle to shift the definitions which accord other people authority. They may decide to review their own resource base by redefining the value of commodities that they, together with other people, possess or can muster up [such as capacities for labour, (dis)loyalty, or voting power].

Checkland and Scholes $(1990$, p. 51) argue that there are many "commodites of power" that observers and participants experience. What is interesting with this point of view is that as their operation is given more exposure, so their relevance and force may be altered. By making more public the way in which meaning is constructed, rules interpreted, and decisions made, power may come to operate in different ways. Some proponents suggest that power may become both spread and enhanced through these social processes. Power as a facility for decision making can become (re)generated in social interaction, through explicit attendance to practices of consultation and participation.

\subsection{Implications for Practice}

The intersubjective decision-making arena of discourse lends itself to new intervention possibilities. Some of these are rendered explicit (e.g., Checkland, 1981; Checkland and Scholes, 1990; Ackoff, 1981, 1993; Lundberg, 1985). The idea, broadly speaking, is that decision making in social life should, as a 
matter of principle, encourage a variety of viewpoints. This variety can be brought to bear when defining options for action. The facility of decision making can be enhanced by nurturing an environment conducive for exchange and development of viewpoints. Achieving this, as seen below, is a tightrope walk for professional theorists and interventionists alike.

Figure 2 advises that action can be taken to aspire to better decisions, i.e., well-considered ones. Well-considered decisions attain enrichment of perspective through the facilitative power of debate. This can be conceptualised as a push up from the point of "decision making" on the $X$ axis toward "most considered" so as to maximise " $b$." The point " $B$ ", marks an ideal, an ideal of most considered decisions informed by a process of debate.

Both "no decisions" and "superdecisions"' stifle choice making and hence suppress freedom. With "no decisions," the extreme left on the $X$ axis, the debating process is presented to participants as if no point of decision is possible. For example, it may be argued that all viewpoints are equally relevant and so

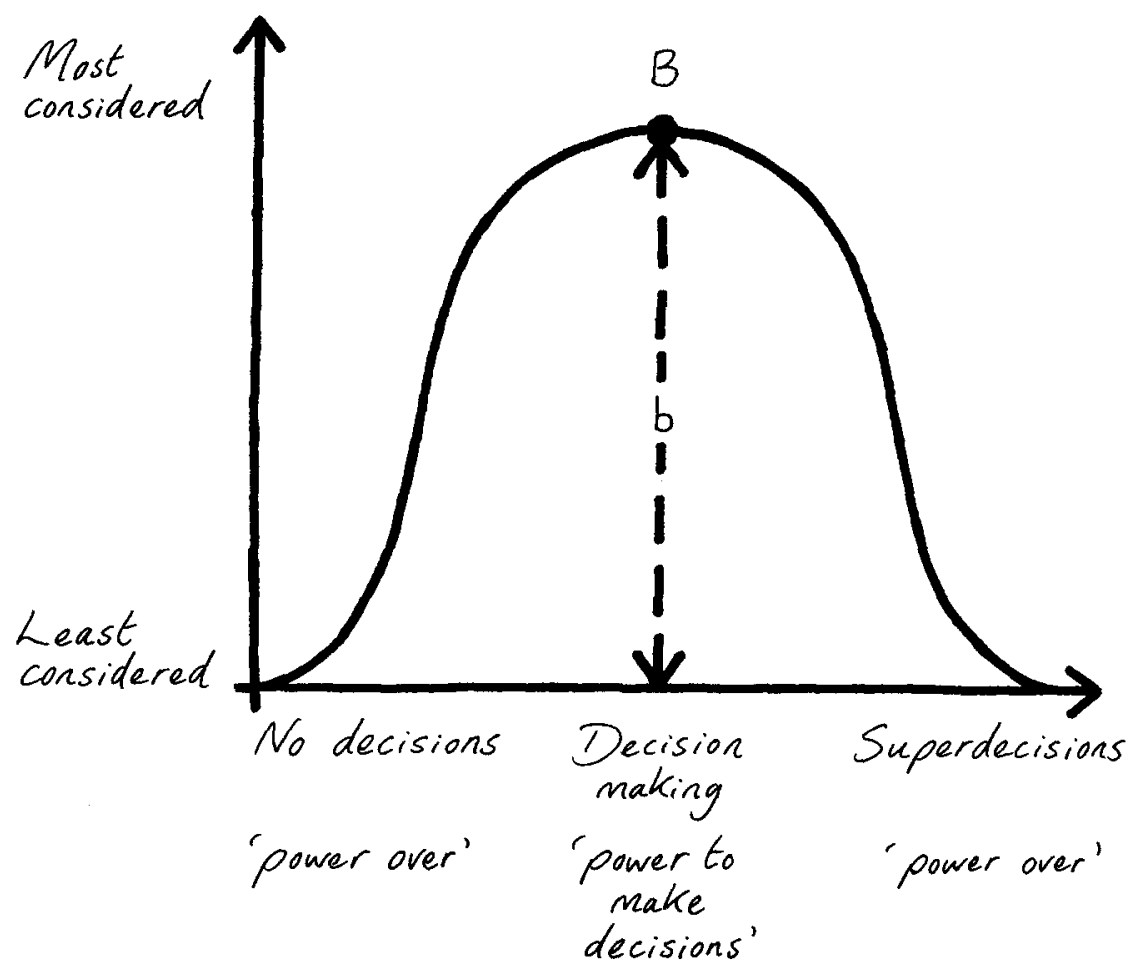

Fig. 2. The intersubjective decision-making arena of discourse: decision-making management. Bachrach and Baratz (1962) would conceive such non-decision making as rooted in "objective" capacity to mobilise bias. Here (in Fig. 2) the focus is on the processes by which "no decisions" are perpetuated. 
there is no basis for choice making. Here, in effect, no decisions are taken and existing power (perhaps power built into stuctures) prevails by default and implements its attendant biases. The further left we move on the graph, the more decisions are experienced as ill considered by many who have to live with their consequences.

With "superdecisions" on the extreme right of the graph, ossified meanings may fix the framework within which all decisions are made. Decision making is thus facile. Decision making is directed by predefined obviousness. This point, or tendency, on the $X$ axis, can also be operative when, for example, it is assumed that decisions have to bear the mark of full consensus of all concerned parties. In this case, superdecisions may become directed by this requirement and accountabilty is then bent toward fulfilling defined arrangements or, at least, seeming to fulfil them. Here, superdecisions created via an appeal to the value of consensus may come to forbid discretionary elements on the part of participants, leading to mistrust of their exercise of choice.

Like the graph on design management, dangers located in the intersubjective decision-making arena of discourse, represented by the extremes on the $X$ axis, are not definable outside of context. It is only in context that assessments can be made about the character of possible abuses. The utility of the graph is the way that it sensitises people to possible dangers and indeed opportunities of which they need to be aware.

It is important to recognise that assessments in this arena may themselves be caught up in a cycle of thinking in which options for action are insufficiently informed by wider considerations. For example, an issue with intersubjective decision making, which is difficult to manage within its own discourse, is how to challenge the rightness of decisions taken. Challenge seems possible only by recourse to given processes of intersubjectivity, during which, using Checkland's (1981, p. 219) terminology, "accommodations"' are pursued. But there are concerns to be raised here. For example, "Once a consensus or compromise [accommodation] upon rightness has been arrived at ... there is no methodological requirement for further challenge"' (Midgley, 1992, p. 166). The next section considers how such challenges may require an alternative discursive agenda. They are discussed under the banner of might-right management.

\section{MIGHT-RIGHT MANAGEMENT}

\subsection{Discourse}

The distinguishing character of this arena of discourse is the degree to which authors (or, rather, arguments) ${ }^{14}$ are concerned about disempowering

\footnotetext{
${ }^{14}$ It is important to remember that what are being categorised in the typology are arguments and these may coalesce more or less with the writings of individual authors. It is useful to have
} 
relationships that become entrenched in social practices. This may indeed occur when people insist on seeking "design solutions" or "decision accommodations" to tackle pressing organisational or societal issues. However, failure to consider power as entrenched in forms of social relationship may mean, inter alia, that people

- fail to activate areas of conflict over issues that people seem to have consented to (see, e.g., Lukes, 1974, p. 32);

- fail to allow for continued moral deliberation over issues which appear resolved (see, e.g., Gutmann and Thompson, 1995, p. 108; Habermas, 1989, pp. 205-208);

- fail to alert participants to the way in which debates may become rigged by the way arguments are (mis)used (see, e.g., Forester, 1987, p. 273);

- fail to consider ways in which conversation may become stacked by the excessive reliance on the force of valid argument as a means of generating fair practice (see; e.g., Lyotard, 1990, p. 340; Jackson and Carter, 1991, p. 125);

- fail to consider and practise counter manoeuvres to address forcefulness of administrative apparatuses which discipline and routinise patterns of relationship (see, e.g., Foucault, 1986, pp. 239-242).

Space to explore some of these issues is opened by debates within and between critical modernism and postmodernism. [Flood and Romm (1996), evoke a variety of these arguments as they pertain to the implications of power for practice.]

\subsection{Implications for Practice}

The focus in this arena of discourse is on power relations brought about by the way the game of knowledge production is played in society. Interventionists may become involved in most serious intrusions into the way knowledge-power relations are directed (see, e.g., Foucault, 1984, pp. 378-379). The grandness of efforts aimed at shifting plays of power in society, and the way in which interventionists should become involved in theorising alternative possibilities, constitutes a subject of contention here. ${ }^{15}$ Another subject of contention in this arena is whether an appeal to the force of the better argument Habermasian-style itself constitutes a form of force, and whether Habermas's reluc-

categories so that one can address the writings of authors and consider the way in which their arguments tend in a specific direction (with consequent implications for practice). This is not to say that authors cannot shift in time their stance in a way which would allow us to recategorise their tendencies. Nor is it to say that theorists are unable to move reflexively between options in their thinking. Indeed it is such reflexivity that is endorsed by diversity management.

${ }^{15}$ See, for instance, Benhabib (1990, pp. 121-122), Hartsock (1990, pp. 164-165), Parker (1993, p. 209), and Gergen (1994, p. 66). 
tance to embrace fundamental dissensus in social life should be seen as threatening in some way. Space limitations in this paper allow only a brief comment on some intervention possibilities in this broad arena of discourse.

Five ways to keep alive this arena of discourse are outlined below.

- Activating the potential for moral deliberation in society by becoming involved in rethinking how fair(er) judgements in social life may be fostered. This includes initiating and vitalising people's education programmes (Freire, 1985; McKay and Romm, 1992), unfurling arguments for a moral citizenry (Habermas, 1993; Gutmann and Thompson, 1995), and/or intervening with the intention of raising and discussing "ought" questions (Ulrich, 1983, 1994; Forester, 1989; Babüroglu and Ravn, 1992).

- Offering theoretical accounts of the way in which processes of knowledge construction in social life may serve to entrench patterns of social domination and suggesting ways in which people may realise mutual respect by rethinking relationships between themselves (Romm and Romm, 1987; Shotter, 1993; Gergen, 1994). This may include involvement in cases that point, perhaps only embryonically, to such potentialities (Gergen, 1994).

- Aiding the vulnerable in society to become more self-reliant whilst creating a base for empowering action (Fals-Borda, 1991; Rahman, 1991). Ideally these initiatives do not aim simply to serve one fraction of people to the detriment of others, unless this form of action itself has gone through considered moral deliberation [see Maghimbi's (1990) discussion of peasant cooperatives in Tanzania and Vanderplaat's (1995) discussion of "empowerment-oriented social programmes."] The intention, in Cohen and Arato's terms (1994, p. 532), is to establish initiatives where involvement with "the system" is not solely about extracting benefits, but is in large part about refreshing modes of relationship.

- Exploring the way in which intelligent protest may be used to resist the demands of "a system" geared to discipline and intransigence in its control function. Protest initiatives are then a critique of the way of life embodied in the pervasion of such administrative rationality in society (see, e.g., Clegg, 1989, pp. 231-239; Cohen and Arato, 1994, pp. 564604). ${ }^{16}$

- Practising what Flood and Romm (1995b) call “oblique" intervention, which addresses the (officially) powerful whilst at the same time under-

\footnotetext{
${ }^{16}$ This is not to say that other domains of discourse offer no thoughts on protest. The point is that in structuralist discourse protest is seen as properly aimed at a critique of structures with the purpose of instituting an alternative. In the intersubjective decision-making arena, protest aims to invigorate cooperative decision making. The researcher may help to make these possibilities visible and hence foster them.
} 
A Typology of Power

351

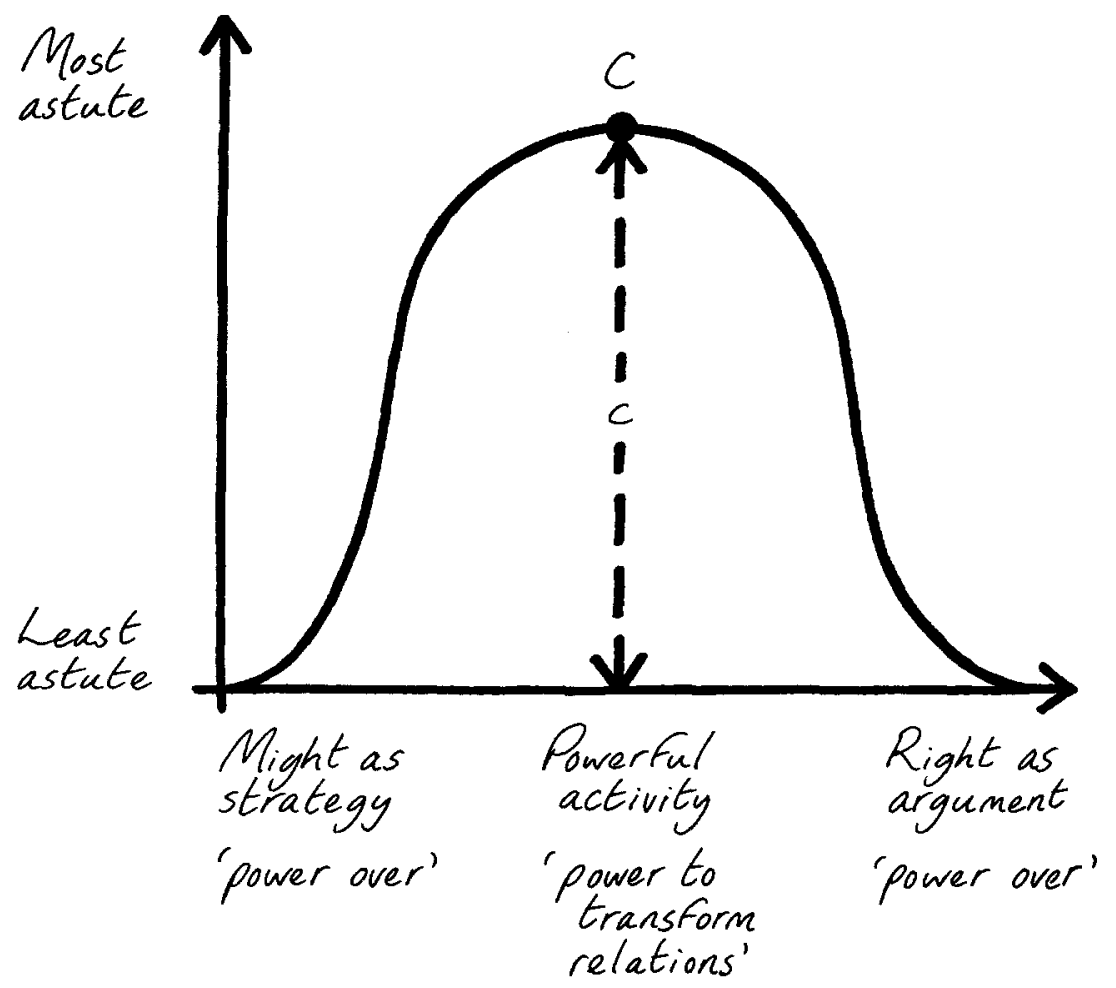

Fig. 3. The might-right management arena of discourse: managing the might-right problematic.

cutting coercive practices, from an angle which strategically redirects designing and debating models and methodologies (see, e.g., Schön, 1989; Payne, 1992; Donnellon and Kolb, 1994).

It is possible to isolate two extreme difficulties faced in the way the game of knowledge production is played in society by bringing together issues raised above. The consolidation is reflected in Fig. 3. The first difficulty, the left extreme on the $X$ axis, is that the might of "power to mobilise" may become seen as the only way to gain empowerment. This, then, means that force, as strategy without attendant moral deliberation, may come to rule. This is manifested, indeed, when so-called liberatory endeavours operate without thought about how more attractive power relationships can be generated. ${ }^{17}$ Some rheorests associate Foucault's position with this abuse (e.g., Nola, 1994, p. 39). It

${ }^{17}$ The terminology "more attractive" comes from Knights and Vurdubakis (1994, p. 189), who note this as an issue that should be recognised. They try to show how a sympathetic reading of Foucault readdresses the issue by considering the possibility of endorsing particular struggles. 
seems, at times, not able to distinguish "better" from "worse" systems of knowledge-power creation. Denzin (1991, p. 41) makes a similar comment regarding Lyotard's micropolitics of subversion. He notes with concern that appeal only to personal conscience, and the denial of the relevance of grand narratives to think through issues of justification, "always leaves open the potential of the very reign of terror he ... so vehemently opposes."

The other danger, the right extreme on the $X$ axis, is sometimes associated by critics with Habermas's argument. It is the danger of unduly endorsing or valorising a set of validation procedures presented as the correct means to generate both truth and rightness in society. The concern is that the force of "better arguments" may come to exclude those less enskilled to enter the exchange, may come to exclude people from utilising other modes of exchange, may come to exclude those who prefer to introduce different criteria of "good" argument into the conversation, etc.

Astuteness in Fig. 3 refers to a consciousness needed to maximise transformative potential in this arena of discourse. Intervention possibilities are chosen judiciously, taking into account the danger of reversion into a might mentality, and conversely a reversion into a mentality relying on good argument, without awareness of its fragility. Efforts of theoreticians and interventionists ideally aim to keep alive the arena so that new modes of social relationship can be explored.

As with the discussion of Figs. 1 and 2, a word of caution is also in order. Care has to be taken not to become bounded by a belief that the engagements plotted in Fig. 3 offer the only possible way of addressing issues faced in all circumstances. The danger of such a perspective is that it inclines the viewer consistently to probe behind specific rulings or accommodations which seem to have been, or which may become, consented to in society. Obsessive probing leads to self generated mistrust of affairs and suspicion of manipulation. Yet the grounding for such mistrust may be circularly related to an initial exclusivity of perspective. This is not to say that the attention given within this arena of discourse to the might-right problematic is exclusivist.

\section{SUMMARY AND CONCLUSION}

To conclude this paper we provide a summary in bullet-list form.

- Intervention suggested by structuralist discourse is about setting up designs that facilitate the way in which collective goals can be served. Structuralism proposes design solutions to potential or actual abuses of power. Structuralist discourse sensitises us to abuses that can occur when design issues are not delicately addressed and managed.

- Intervention suggested by intersubjective decision-making discourse con- 
centrates on ways that people make decisions in conjunction with other people (or agents). Theorists of this persuasian do not believe that the way events work out in everyday life is due to capacities written into social rules, or resource distribution, or official definitions of authonity, or any other feature of design. They prefer to highlight the central role of agency in both defining and using rules and resources and authority.

- Intervention suggested by might-right discourse addresses power relations brought about by the way the game of knowledge production is played in society. The grandness of efforts aimed at shifting plays of power in society, and the way in which interventionists should become involved in theorising alternative possibilities, constitutes a subject of contention here. Another subject of contention in this arena is whether an appeal to the force of the better argument itself constitutes a form of force, and whether reluctance to embrace fundamental dissensus in social life should be seen as threatening in some way.

In this paper we have introduced a typology of power. It forms three arenas of discourse around three types of intervention: structuralism, intersubjective decision making, and might-right management. The arenas of discourse isolated by the typology not only provide different conceptions of power, but also suggest possible practical responses to abuses of power. Treading a path between and around the various issues requires some careful consideration. Our own considerations are expanded upon by Flood and Romm (1996). An argument is created for the possibility of interventionists "looping" between options provided by the different arenas of discourse, so as to retain sensitivity to the dilemmas, but also responsibilities involved in managing the practice of power.

\section{REFERENCES}

Ackoff, R. L. (1981). Creating the Corporate Future, Wiley, New York.

Ackoff, R. L. (1993). Idealised design: Creative corporate visioning. OMEGA 21, 401-410.

Babüroglu, O. N., and Ravn, I. (1992). Normative action research. Organis. Stud. 13, 19-34.

Bachrach, P., and Baratz, M. S. (1962). Two faces of power. Am. Polit. Sci. Rev. 56, 947-52.

Beer, S. (1973). Designing Freedom, Canadian Broadcasting, Toronto.

Benhabib, S. (1990). Epistemologies of postmodemism: A rejoinder to Jean-François Lyotard. In Nicholson, L. J. (ed.), Feminism/Postmodernism, Routledge, New York.

Bhaskar, R. (1993). Dialectic: The Pulse of Freedom, Verso, London.

Bhaskar, R. (1994). Plato Etc., Verso, London.

Checkland, P. B. (1991). Systems Thinking, Systems Practice, Wiley, Chichester.

Checkland, P. B., and Scholes, J. (1990). Soft Systems Methodology in Action, Wiley, Chichester.

Clegg, S. R. ([989). Frameworks of Power, Sage, London.

Cohen, J. L. and Arato, A. (1994). Civil Society and Political Theory, MrT Press, Cambridge, MA.

Czarniawska-Joerges, B. (1993). The Three-Dimensional Organization, Studentlitteratur, Lund. 
Dahl, R. (1961). Who Governs? Democracy and Power in an American City, Yale University Press, New Haven, CT.

Dandridge, T. C. (1985). The life stages of a symbol: When symbols work and when they can't. In Frost, P. J. Moore, L. F., Louis, M. R. Lundberg, C. C., and Martin, J. (eds.), Organizational Culture, Sage, London.

Denzin, N. K. (1991). Images of Postmodern Society, Sage, London.

Donnellon, A., and Kolb, D. M. (1994). Constructive for whom? The fate of diversity disputes in organizations. J. Soc. Issues 50, 139-55.

Fals-Borda, O. (1991). Some basic ingredients. In Fals-Borda, O., and Rahman, M. A. (eds.), Action and Knowledge, Apex Press, New York.

Flood, R. L. (1993). Practicing freedom: Designing, debating and disemprisoning. OMEGA 21, 7-16.

Flood, R. L. (1995). Solving Problem Solving, Wiley, Chichester.

Flood, R. L., and Romm, N. R. A. (1955a). Diversity Management: Theory in action. Syst. Pract. 8, 469-482.

Flood, R. L., and Romm, N. R. A. (1995b). Enhancing the process of methodology choice in Total Systems Intervention (TSI) and improving chances of tackling coercion. Syst. Pract. 8, 377-482.

Flood, R. L., and Romm, N. R. A. (1996). Diversity Management: Triple Loop Learning, Wiley, Chichester (in press).

Forester, J. (1987). The policy analysis-Critical theory affair: Wildavsky and Habermas as bedfellows. In Forester, J. (ed.), Critical Theory and Public Life, MIT Press, Cambridge, MA.

Forester, J. (1989). Planning in the Face of Power, University of California Press, London.

Foucault, M. (1984). In Rabinow, P. (ed.), The Foucault Reader, Penguin, Harmondsworth.

Foucault, M. (1986). Disciplinary power and subjection. In Lukes, S. (ed.), Power, Basil Blackwell, Oxford.

Freire, P. (1985). The Politics of Education: Culture, Power, and Liberation, Bergin and Garvey, MA.

Fuenmayor, R., and Lopez-Garay, H. (1991). The scene for Interpretative Systemology. Syst. Pract. 4, 401-418.

Gergen, K. J. (1994). The limits of pure critique. In Simons, H. W., and Billig, M. (eds.), After Postmodernism: Reconstructing Ideology Critique, Sage, London.

Giddens, A. (1977). Studies in Social and Political Theory, Hutchinson, London.

Gouldner, A. W. (1973). The Coming Crisis of Western Sociology, Basic Books, New York.

Gutmann, A., and Thompson, D. (1995). Moral disagreement in a democracy. In Social Philos. Policy 12, 87-110.

Habermas, J. (1989). The Structural Transformation of the Public Sphere, Polity, Cambridge.

Habermas, J. (1993). Justification and Application: Remarks on Discourse Ethics, Polity, Cambridge.

Hartsock, N. (1990). Foucault on power: A theory for women? In Nicholson, L. J. (ed.), Feminism/ Postmodernism, Routledge, New York.

Hofstede, G. (1994). Uncommon Sense About Organizations, Sage, London.

Jackson, N., and Carter, P. (1991). In defence of paradigm incommensurability. Organiz. Stud. 12, 109-127.

Knights, D., and Vurdubakis, T. (1994). Foucault, power, resistance and all that. In Jarmier, J. M., Knights, D., and Nord, W. R. (eds.), Resistance and Power in Organizations, Routledge, London.

Knorr-Cetina, K. (1988). The micro-social order: towards a reconception. In Fielding, N. G. (ed.), Actions and Structure: Research Methods and Social Theory, Sage, London.

Kuhn, T. S. (1970). The Structure of Scientific Revolutions, University of Chicago Press, Chicago. 
Lukes, S. (1974). Power: A Radical View, Macmillan, London.

Lundberg, C. C. (1985). On the feasibility of cultural intervention in organizations. In Frost, P. J., Moore, L. F., Louis, M. R., Lundberg, C. C., and Martin, J. (eds.), Organizational Culture, Sage, London.

Lyotard, J. F. (1990). The postmodern condition. In Alexander, J. C., and Seidman, S. (eds.); Culture and Society: Contemporary Debates, Cambridge University Press, Cambridge.

Maghimbi, S. (1990). The abolition of peasant cooperatives and the crisis in the rural economy in Tanzania. In Forster, P. G., and Maghimbi, S. (eds.), The Tanzanian Peasantry: Economy in Crisis, Avebury, Aldershot.

McKay, V. I., and Romm, N. R. A. (1992). People's Education in Theoretical Perspective, Maskew Miller Longman, Cape Town.

Midgley, G. (1992). Pluralism and the legitimation of systems science. Syst. Pract. 5, 147-172.

Morgan, G. (1980). Paradigms, metaphors, and puzzle solving in organization theory. Admin. Sci. Q. 25, 605-621.

Moggridge, A., and Reason, P. (1996). Human inquiry: Steps towards emancipatory practice. Syst. Pract. 9, 159-175.

Nola, R. (1994). Post-modernism, a French cultural Chernobyl: Foucault on power/knowledge. Inquiry 37, 3-43.

Ojo, O. J. B. (1983). Towards a development oriented political science curriculum. In Barongo, Y. (ed.), Political Science in Africa, Zed Press, London.

Oliga, J. (1996). Power, Ideology and Control, Plenum, New York.

Parker, M. (1993). Life after Jean-François. In Hassard, J., and Parker, M. (eds.), Postmodernism and Organizations, Sage, London.

Parsons, T. (1957). The distribution of power in American society. World Polit. 10, 123-143.

Parsons, T. (1963). On the concept of influence. Public Opin. Q. 27, 37-62.

Parsons, T. (1973). Social classes and class conflict in the light of recent sociological theory. In Thompson, K., and Tunstall, J. (eds.), Sociological Perspectives, Penguin, Harmondsworth.

Payne, S. L. (1992). Critical Systems Thinking: A challenge or dilemma in its practice? Syst. Pract. $5,237-249$.

Rahman, M. A. (1991). The theoretical standpoint of PAR. In Fals-Borda, O., and Rahman, M. A. (eds.), Action and Knowledge, Apex Press, New York.

Romm, N. R. A. (1994). Symbolic theory. In Romm, N. R. A., and Sarakinsky, M. (eds.), Social Theory, Heinemann, Johannesburg.

Romm, N. R. A., and Romm, N. (1987). Militarising tolerance. De Arte 36, 23-25.

Sayer, A., and Walker, R. (1992). The New Social Economy, Basil Blackwell, Cambridge, MA.

Schön, D. A. (1989). Supplement on planning education: Teaching planning practice. Case study presented in Forester, J. (ed.), Planning in the Face of Power, University of California Press, Berkeley.

Shotter, J. (1993). Cultural Politics of Everyday Life, Oxford University Press, Buckingham.

Ulrich, W. (1983). Critical Heuristics of Social Planning: A New Approach to Practical Philosophy, Haupt, Berne.

Ulrich, W. (1994). Can we secure future-responsive management through Systems Thinking and Design? Interfaces 4, 26-37.

Vanderplaat, M. (1995). Beyond technique: Issues in evaluating for empowerment. Evaluation 1, $81-96$.

Wrong, D. H. (1995). Power: Its Forms, Bases and Uses, Transaction, New Brunswick, NJ.

Zhichang, Z. (1995). Government policy/decision making: Dealing with contestable interests. In Bergvall-Kareborn, B. (ed.), Systems Thinking, Government Policy and Decision Making, Proceedings of the Thirty-Ninth Annual Meeting of the International Society for Systems Science. 